\title{
Satisfaction of Preparatory Year Students with University Services
}

\author{
Omear S Alghamdi ${ }^{1,2, *}$ \\ ${ }^{1}$ Educational Administration and Planning Department, Faculty of Education, Al-Baha University, Baha, KSA \\ ${ }^{2}$ Department of Educational Leadership Research and Technology, Western Michigan University, Kalamazoo, USA \\ *Correspondence: Educational Administration and Planning Department, Faculty of Education, Al-Baha University, \\ Baha, zip 65411, Saudi Arabia. Tel: 966-556-677-684. E-mail: omair4418@yahoo.com
}

Received: September 22, 2015

Accepted: October 5, $2015 \quad$ Online Published: October 11, 2015

doi:10.5430/wje.v5n5p117

URL: http://dx.doi.org/10.5430/wje.v5n5p117

\begin{abstract}
This study is aimed at evaluating the level of satisfaction of preparatory year students at Al-Baha University with the academic and non-academic services they receive, and determining whether there were any differences in student satisfaction on the basis of personal variables (gender, college, distance). This research used quantitative descriptive approach. To collect study data, a questionnaire consisting of fifty items within seven prime satisfaction dimensions was used. They were distributed to a stratified random sample of 350-strong regular students in the preparatory year for the academic year 2014-2015. Using appropriate statistical methods, the results of the study showed an average level of satisfaction of preparatory year students with student services they receive, and the results revealed statistically significant differences in the level of student satisfaction attributed to the variable distance between the university and housing. According to the results, the study provided a set of recommendations aimed at developing the student services and meeting the expectations of students in order to achieve quality in the inputs and outputs of the university.
\end{abstract}

Keywords: preparatory year; student satisfaction; university services

\section{Introduction}

Although the change in visions and policies that has begun since the eighties of the last century and the trend towards creating a marketplace for higher education have succeeded in providing a wide range of colleges and universities that meet the wishes of students, we are locking for what puts the providers in a fierce competition to attract them (Hussey \& Patrick, 2010). Sparking the competition among institutions of higher education to win the largest share of students, especially outstanding ones, and bring a lot of subsidies, requires outperforming of these institutions, improving their programs and developing many of the initiatives supporting the student success and helping the students achieve satisfaction. The customer satisfaction is seen as a safety valve of quality; some even define quality as the extent to which service quality can reach in meeting the beneficiaries' expectations or surpassing them (Bani Hamdan, 2012).

So many successful institutions realized the importance of customer satisfaction, and the need to follow up their reactions and evaluate their satisfaction, as they regard customer satisfaction with their services as a strategic asset that has a significant effect on other current clients or clients they expect to deal with in the future (Hussey \& Patrick, 2010).

In higher education fields, evaluation of student satisfaction is seen as the most important activity as a result of its role in identifying the quality of student services provided by the university or college. The high levels of satisfaction are reflected positively on the academic achievement of the students and help reduce dropout ratios of educational programs before completion (Astin, 1993). Studies indicate that satisfaction surveys play a key role in customer retention (Roszkowski \& Ricci, 2005). This in turn positively affects the financial performance of the educational institutions (Ryals, 2002).

In Saudi Arabia, many of the initiatives and experiments are carried out in order to improve the inputs and outputs of higher education, and there is still more work to be done, including evaluating these experiences and working on improving them. Preparatory year is one of those experiments, but this experiment has been and remains a matter of 
debate among researchers and those who are interested in educational affairs locally, despite maturation of the experiment internationally. Many of the acclaimed critiques have been directed to this experiment and began to be seen as an item in the list of higher education problems (Kamel, 2015). Voices of dissatisfaction pointing to weakness of its quality and low level of objective achievement have been raised. It rather exceeds that point, as stated in Al-Riyadh newspaper report (2012), many of students' parents filed complaints to the Shura Council against preparatory year program in Saudi universities calling for it to be canceled. The parents justified that with the program weakness and its negative effects on the future of their children in proportion to its positives and huge budgets incurred by the state for running it, the program is not effective. In addition, the factual information refers to many problems associated with employment and faculty staff, which were confirmed by one of the deans of preparatory year when saying, "Most of preparatory year programs provide copies contradicting the ideal one, especially when it comes to hiring teachers who come from different backgrounds and with different experiences" (Rice, 2015, P.63).

There is no doubt that preparatory year involves many of challenges that face student as a result of his/her transfer from the less independent school environment to the more open, free and self-reliant university environment. This in turn requires the universities to care more about the quality of academic life in preparatory year and not to tolerate the implementation of Care programs, run them in cooperation with ill-qualified institutions, nor recruit non-professional teaching staff. This confirms the results of the first National conference of preparatory year in Saudi universities (2015), which emphasized the importance of preparatory year in Saudi universities, the need to continue applying it, and the work on evaluating and continuously improving its programs and methods of employment.

Although researchers are inconsistent with the nature of the relationship between service quality and customer satisfaction and which one of them leads to the other (Douglas, McClelland, \& Davies, 2008), students satisfaction represents a prime quality indicator and important factor in the supremacy and success of the educational organization (Budic, 2011). This research is going in the direction believing that service quality leads to student satisfaction. Therefore, the researcher takes from the method of evaluating satisfaction of preparatory year students at Al-Baha University a framework to know the reality of student service quality provided to them.

\subsection{Preparatory Year in Saudi Universities}

The Association of American Colleges and Universities (2007) indicates that achieving the objectives of university systems requires basic educational outcomes and acquisition of a wide range of specific skills by graduates. There is no doubt that these skills will contribute to the independence of student learning and developing their abilities to create goals and challenge the obstacles that face them in the future.

Studies have indicated to the ability of the first two years of university study to predict the reliable levels of academic performance of students (Pascarella \& Terenzini, 2005). So, international experiments of university education advancement have generated a lot of models and visions of development including preparatory year or so-called first year. This first year is seen as a package of measures aiming at facilitating the integration of students in university education and supporting their learning programs. Therefore, preparatory year is defined as follows:

The first-year experience is not a single program or initiative, but rather an intentional combination of academic and co-curricular efforts within and across postsecondary institutions. . [That represent] a purposeful set of initiatives designed and implemented to strengthen the quality of student learning and satisfaction during the first year of college- the stage in American higher education during which the largest proportion of university dropout occurs. (Koch \& Gardner, 2006, p. 2).

Mostly, preparatory year involves methodological plans to train students, provide them with specific skills through many effective practices, and involve them in academic challenges and scientific activities that require further analysis, synthesis, theories activation and judgment (Khalil, 2010). Keup (2014) points to seven key fields that represent the target outputs range of preparatory year, namely: (1) student retention; (2) academic skills; (3) communication skills; (4) personal relations skills; (5) personal developing skills; (6) democratic civic participation; (7) employability.

The Saudi Arabian experience in admission of preparatory year to university-education programs has been associated with establishing King Fahd University of Petroleum \& Minerals in 1963 (Kamel, 2015). However, the rapid expansion witnessed in higher education in the Kingdom of Saudi Arabia and the accompanying development of university plans and programs in the twenties of this century resulted authorization of preparatory year at all universities. It is a university initial stage aimd at preparing students academically, socially, psychologically and culturally, and providing them with multiple skills to help them communicate well with their community, and 
constructing successful study habits for independent learners that have capabilities and skills enable them to move forward in the fields they want to study. Preparatory year in its current form represents an educational program that lasts for two semesters, and student is required to pass it before joining the specialization for which $\mathrm{s} / \mathrm{he}$ nominated in the university, according to his/her abilities and inclinations (Kamel, 2015).

\subsection{Student Satisfaction toward University Services}

Student satisfaction involves all judgments that reflect their feelings towards the performance of teachers, teaching methods and courses, and all services offered by the university for students, including educational and non-educational activities, and registration services, office and health services, as well as housing facilities, nutrition and academic counseling and so on (Amarat \& Thawabieh, 2011).

Student satisfaction is an indicator of efficiency and effectiveness of the programs (Mohammed, 2004). It is often achieved through the availability of a set of conditions and standards in the academic and non-academic services offered by the University (Saif, Sartawi \& Aqra, 2014). However, the lack of student satisfaction may be due, in some cases, to factors related to students themselves, such as weakness of tendencies towards specialization, or lack of the necessary skills that the university should take into account (Nabhan, 2001). The university should work on measuring student satisfaction, identify the factors causing dissatisfaction and handling them.

Some liken measuring student satisfaction to accounting profit and loss in the business sector. If the level of satisfaction is high, the university will be in a state of profit where its objectives are achieved, the student will enjoy his/her academic attainment and university life more, which is reflected on his/her positive speech about the university. In contrast, the low levels of satisfaction, reflecting loss of the university and lack of achieving its objectives and student expectations, may lead to transition of students to other universities, and not recommending it to others to study in, or talking about it negatively (Sumadi, Bakti \& Metasari, 2011).

Students usually resort to express their discontent and dissatisfaction through social media, and other means of communication; and this would tarnish the institution's reputation and affect its position negatively (Mansori, Vaz \& Ismail, 2014).

It is worth mentioning, that student feelings of satisfaction with university services are no longer achieved once these services are available, it has become more closely related to the level of this service quality, and the degree of distinction. It is also influenced by their multiple comparisons with what is offered to their counterparts at other universities, and this of course raises the level of expectations about diversity and quality of student services, and forms renewed challenges for universities (Ilias \& Nor, 2012), under considering quality as elusive recipe that has no limits (Bernhard, 2011).

In spite of regarding quality as an integral part of the professional responsibilities of academics (Harvey \& Akling, 2003), and considering the member of teaching staff as a leader and champion in succeeding the student initiatives for preparatory year, the recent trends call for improving the performance of the all components within the campus, involving them in student-success initiatives and accounting them for meeting the requirements and achieving satisfaction (Greenfield, Keup \& Gardner, 2013).

Therefore, this study adopts measuring the satisfaction of preparatory year students through more extensive fields (teachers and teaching methods, course content, testing and evaluation, management of student affairs, academic counseling, learning resources, facilities and supporting services), as they are fields of vast sectors of university activities targeted by quality operations (National Commission for Academic Accreditation \& Assessment - NCAAA, 2011). Also, these fields are the most influential in student satisfaction (Amarat \& Thawabieh, 2011).

\subsection{Previous Studies}

As student satisfaction is important, many studies have been conducted in terms of satisfaction with a specific program, particular college or stand-alone service. Lal (1999) conducted a study aimed at identifying satisfaction of post-graduate students in colleges of education in three Saudi universities. The study sample consisted of 90 students enrolled in three different disciplines. Results showed a lack of statistically significant impact of the variables gender and specialization on satisfaction with the study in the program.

Amarat and Thawabieh study (2011) aimed at constructing an instrument that has high psychometric properties to measure degree of student satisfaction with their studies at Tafila Technical University. The instrument consisted of 47 items distributed to five fields. Results showed moderate degrees of satisfaction. These scores did not differ depending on the variables gender and academic level, while differences attributed to college variable were proven only in services. 
In addition, Nabhan (2001) has developed an instrument with psychometric properties to measure the level of satisfaction of Faculty of Educational Sciences students with studying at Mutah University. The instrument consisted of 33 items distributed to four fields. Results showed that degrees of student satisfaction were moderate. Moreover, it did not differ depending on the variables gender and stage of study.

On the other hand, Hamda's study (2012) aimed at demonstrating the impact of educational-service quality on student satisfaction at Applied Science Private University. In order to achieve the study objectives, the researcher designed a questionnaire including 28 items to collect data from students. The study reached a conclusion that a higher level of educational-service quality reflects a higher level of student satisfaction.

Sarmi and Zayed's study (2006) aimed at identifying Faculty of Education degree of student satisfaction with academic supervision services provided to them, as well as exploring their expectations. The study sample consisted of 501 male and female students enrolled at the Faculty of Education. The results of the study revealed that the students of Faculty of Education were not satisfied enough with academic supervision. They also indicated that by increasing the number of times students met their supervisor, the student satisfaction with academic supervision increased.

Also, Qudah and Khleifat (2013) conducted a study aimed at investigating the degree of Mutah University student satisfaction with university services. In order to achieve that, a questionnaire distributed to a sample of 449 male and female students was prepared. Results showed a moderate degree of student satisfaction with their studies and fields, and revealed the same statistically significant differences in degree of student satisfaction with university services in Mutah University in the field of library services attributed to the variable of college and the college interaction with grade point average. However, the study did not show statistically significant differences related to gender.

The study conducted by Hassania (2009) aimed at measuring the level of student satisfaction with administrative and academic performance of Faculty of Economics at Aleppo University. The questionnaire has been used as an instrument for measuring a sample of 290 under and post-graduate students. Results showed that the overall level of satisfaction with the ten studied fields ranged between good in the field of teaching staff performance, acceptable in the field of scientific research, and weak in all other fields. The results also showed that there are no significant differences in the level of satisfaction attributed to all demographic variables the study included.

In a study conducted by DeShields, Kara and Kaynak (2005), the focus was on the determinants of student satisfaction and retention which are supposed to affect the experiences of university students. The questionnaire has been distributed to a sample of 160 students to collect data of the study; path analysis was also used to experimentally test the hypothesized effects via incorporating a comprehensive set of independent variables and conducting experiments to predict which experiences are believed to be related to student satisfaction. The results indicated that the transaction path from teaching staff and classes to the partial university experience of the student is consistent with the hypothesis that these are the main factors that affect the partial university experience of the student. In addition, it turns out that students who had positive university experience were more likely to be satisfied with the college or university than students who did not have positive college experience.

Abbasi, Malik, Chaudhry and Imdadullah (2011) also conducted a study to measure the level of student satisfaction with the current services provided by Bahauddin Zakariya University. The sample consisted of 401 male and female students enrolled in eighteen specialties in various programs. The results showed that students were dissatisfied with many of the basic services and facilities such as education, administrative support, library, laboratories, housing, medical care, and sport programs, while they revealed the satisfaction of students in three fields, i.e., transportation, classroom and facilities intended for prayer; no significant differences in opinion among male or female respondents were reported. Generally, the study confirms that the satisfaction level is worrying; the results indicate a lack of student satisfaction with educational services offered by the university.

Howell and Buck's study (2012) has aimed at constructing a proposed model of student satisfaction with courses, as satisfaction is an important factor that can contribute to student retention and can be used as a means of evaluating the effectiveness of teaching staff. Two questionnaires have been used; the first was distributed to a sample size of 214 members of teaching staff, while the second has been distributed to 1725 participating students from five institutions of higher education. The results of the study concluded to four variables affecting student satisfaction which are: (1) relevancy of subject-matter, (2) faculty subject-matter competency, (3) faculty classroom management, (4) student workload.

At the University of Sassari in Italy, a study conducted by Solinas, Masia, Maida and Muresu (2012) was aimed at exploring the satisfaction of students attending courses at Faculty of Science, and identifying the aspects of teaching 
that may cause dissatisfaction among students to prevent them from dropping out of their university study. Emphasis was placed on studying the relationship between student satisfaction and three variables; motivation, quality of teaching, and services. Analysis outputs of 403 collected questionnaires clarified several results; the most important of these results is that an interest in sciences was the main motivation really affecting student satisfaction, followed by the ambition to work in the future. In addition, the teacher's ability to keep students' attention and motivate and advise them played an important role in their satisfaction. The results also showed that the efficiency of the services had a positive impact on student satisfaction.

Generally, most results of the studies on student satisfaction refers to the necessity of following the students' needs, working on satisfying them, seeking permanently to meet their expectations in the diversity of services provided to them and its quality level, and working on providing a positive university climate that supports teaching and learning processes and contributes to increasing their satisfaction with studying at the university, all of which have a positive impact on all parties.

\section{The Study Problem and Question}

The efforts of education development in the Kingdom of Saudi Arabia provide preparatory year as a therapeutic framework to bridge the gap between general education outputs and higher education inputs in order to form multi-disciplinary skills contributing to improving the student performance. In the light of the factual information about the negative outlook of the majority of students towards preparatory year in its current state, regarding it as an additional burden where there is no such desired benefit compared to the period of time spent by the student in order to complete the program requirements; therefore the researcher of this study regards measuring student satisfaction with preparatory year at Al-Baha University as an indicator for verifying the quality of their academic life and revealing weaknesses and shortcomings in the services provided to them. More specifically, the study problem is summarized in the following main question:

What is the level of preparatory year student satisfaction at Al-Baha University with the services they receive?

\section{The Study Hypotheses}

This study aimed to examine the following hypotheses:

- Ho1 There are no significant differences at the level of significance of $(\alpha \leq 0.05)$ in the levels of satisfaction of preparatory year students toward services they receive at Al-Baha University based on the variable of gender.

- Ho2 There are no significant differences at the level of significance of $(\alpha \leq 0.05)$ in the levels of satisfaction of preparatory year students toward services they receive at Al-Baha University based on the variable of college.

- Ho3 There are no significant differences at the level of significance of $(\alpha \leq 0.05)$ in the levels of satisfaction of preparatory year students toward services they receive at Al-Baha University based on the variable of distance between residence and the university.

\section{The Study Objectives}

There are three basic objectives of this study, i.e., (1) describing the level of satisfaction among preparatory year students with the services provided to them at Al-Baha University, (2) determining whether there are differences in student satisfaction on the basis of demographic variables, (3) providing university leaders and officials with factual information on preparatory year about the level of what is offered in preparatory year program of services and the extent of achieving students' requirements and expectations as they are the target of these efforts and the first beneficiary of them.

\section{Significance of the Study}

The importance of this study emerges in adopting the concepts of modern educational theories that emphasize the learner participation in the evaluation of services they received (Saif, Sartawi \& Aqra, 2014). Student satisfaction is the university mirror via which level of performance is recognized (Amarat \& Thawabieh, 2011). It is also an important indicator for verifying the quality of services, and the extent of meeting needs and expectations of students who are the direct beneficiary of the service. Generally, this study will provide decision-makers at the university with 
valuable information, which we hope to take advantage in handling the deficiencies and the development of performance to achieve the objective of preparatory year program.

\section{Limitations of the Study}

- The study was limited to measuring the satisfaction of the preparatory year students at Al-Baha University with the services they receive.

- The study was limited to the preparatory year students who have completed the first semester of the academic year 2014-2015.

- The study was limited to the preparatory year students who were studying in the main campus in Al-Aqiq province for males and in Al Baha city for females.

\section{Methodology and Procedures}

In order to identify the level of satisfaction of preparatory year students at Al-Baha University with the services they receive, this study followed the descriptive method survey that focuses on describing a phenomenon under study. This method works through distributing a questionnaire among all of a study population or a large sample of it in order to reach conclusions contributing to the improvement of the real world.

\subsection{Sample and Data Collection}

The study population consisted of all the preparatory year students at Al-Baha University for the academic year 2014-2015. Their number has reached 2449 male and female students, according to the statistics of preparatory year Deanship. Since the appropriate sample size to achieve the purpose of the study is 332 individuals (Krejcie \& Morgan, 1970), 350 questionnaires have been distributed manually after selecting participants. The stratified random sampling way was used to determine the sample search. All necessary guarantees have been taken to obtain the required number of valid questionnaires to be studied; the full number of questionnaires has been retrieved. Thus, the questionnaires included in the analysis represent $100 \%$ of the number of distributed questionnaires, and $14.29 \%$ of the study population. Table 1 shows the sample distribution according to the study variables.

Table 1. Distribution of Study Sample According to Demographic

\begin{tabular}{cccccccc}
\hline Variable & Level & Frequency & $\%$ & Variable & Level & Frequency & $\%$ \\
\hline \multirow{2}{*}{ Gender } & Male & 183 & 52.3 & & \multirow{2}{*}{$\leq 20 \mathrm{~km}$} & \multirow{2}{*}{84} & \multirow{2}{*}{24} \\
& Female & 167 & 47.7 & \multirow{2}{*}{ Distance } & & & \\
\multirow{2}{*}{ College } & scientific disciplines & 163 & 46.6 & & \multirow{2}{*}{$>20 \mathrm{~km}$} & \multirow{2}{*}{266} & 76 \\
& literary disciplines & 187 & 53.4 & & & \\
\hline
\end{tabular}

\subsection{The Research Instrument}

To achieve the objectives of the study, the researcher developed a questionnaire based on the literature and related previous studies, as well as the instrument based on standards of quality assurance and academic accreditation of higher education institutions in the Kingdom of Saudi Arabia (NCAAA, 2011). The final form of the instrument consisted of two parts; the first part included some preliminary data of the participant. The second part included 50 items to measure student satisfaction distributed on seven key dimensions. The instrument was judged by 9 members of teaching staff in the Faculty of Education at Al-Baha University. In the light of their suggestions, some items have been modified, replaced, or deleted. By following the agreement of more than $70 \%$ of the arbitrators, the final version of the questionnaire consisted of 50 items, which was initially made up of 60 items. To ensure the reliability of the instrument, the researcher calculated Cronbach's coefficient alpha - (Cronbach's Alpha) (Table 2); reliability values range between $0.84-0.92$ for the dimensions, while the reliability value of the instrument as a whole 0.91 , all of which are acceptable values to confirm the reliability of the questionnaire phrases and their validity to achieve the purpose of the study. 
Table 2. Reliability of the Instrument

\begin{tabular}{clc}
\hline list & Dimension of student satisfaction & Reliability Cronbach's Alpha \\
\hline A & Faculty Members and Teaching Methods & 0.87 \\
B & Course Content & 0.84 \\
C & Exams and Evaluation & 0.92 \\
D & Management of Student Affairs & 0.90 \\
E & Academic Advising & 0.89 \\
F & Learning Resources & 0.86 \\
G & Facilities and Support Services & 0.85 \\
\hline & Overall & 0.91 \\
\hline
\end{tabular}

To determine the degree of respondent satisfaction with the instrument items in its second part, use Five-Point Likert scale, with options including: very high, high, average, Low, and very low. For rating averages and identifying degree of satisfaction, the scale has been modulated from five to three points. Therefore, the final estimation degrees of arithmetic average and percentages are determined according to the following:

$\circ$ The arithmetic average of 3.661-5.00 and the percentage of $73.21 \%-100 \%$ show a high level of satisfaction.

- The arithmetic average of $2.331-3.66$ and percentage of $46.61 \%-73.20 \%$ show a moderate level of satisfaction.

- The arithmetic average of $1.00-2.33$ and percentage of $1.00 \%-46.60 \%$ show a low level of satisfaction.

In general, the researcher uses the arithmetic average 3.00, and percentage $60 \%$ as the borderline of evaluation, whenever the degree of arithmetic average or percentage of the item, dimension or scale as a whole is higher than $3.00 / 60 \%$, it expresses a tendency to satisfaction. In contrast, whenever the values are lower than $3.00 / 60 \%$, they express a tendency to dissatisfaction.

\subsection{The Statistical Processing}

The data processed by Statistical Package for Social Sciences (SPSS). Thus, the researcher used descriptive statistics including duplicates, averages, and percentages; he also used analytical statistics representing in Cronbach's Alpha and T-Test.

\section{Result and Discussion}

The purpose of this study is to evaluate the satisfaction of preparatory year students with academic and non-academic services provided to them at Al-Baha University.

\subsection{Results Related to the Study Question}

What is the level of satisfaction of preparatory year students at Al-Baha University with the services they receive?

To answer this question, averages and percentages of the participant responses are calculated to each dimension of the student satisfaction scale in addition to the total score of the scale (Table 3).

Table 3. Average, Percentages, and Dimension Score

\begin{tabular}{clccc}
\hline No & \multicolumn{1}{c}{ Dimension } & Avg. & \% & Level \\
\hline C & Dimension of Exams and Evaluation & 3.17 & 63.5 & Average \\
D & Dimension of Management of Student Affairs & 3.15 & 63.1 & Average \\
A & Dimension of Faculty Members and Teaching Methods & 2.66 & 53 & Average \\
G & Dimension of Facilities and Support Services & 2.64 & 52.7 & Average \\
B & Dimension of Course Content & 2.52 & 50.4 & Average \\
F & Dimension of Learning Resources & 2.40 & 48.0 & Average \\
E & Dimension of Academic Advising & 2.02 & 40.4 & Low \\
\hline & Satisfaction overall & $\mathbf{2 . 6 5}$ & $\mathbf{5 3 . 0}$ & Average \\
\hline
\end{tabular}

Table 3 shows that the satisfaction level of the study sample is moderate, as the value of the arithmetic average reaches 2.65 and the total percentage reaches $53 \%$. When taking into account that the borderline between satisfaction 
and dissatisfaction in this study is $(3.00 / 60 \%)$, this result reflects the dissatisfaction of preparatory year students at Al-Baha University for services provided to them. Regarding the seven dimensions of the scale, tests and evaluation dimension came in the first place with moderate degree, but not much beyond the borderline, as the value of the arithmetic average reaches 3.17 and with the percentage equaling $63.5 \%$. The academic counseling dimension came in the last place with a low degree of student satisfaction, as the value of its arithmetic average reaches 2.02 with the percentage equaling $40.4 \%$. All the remaining five dimensions reported moderate satisfaction distributing to a range of 0.75 . In general, the results of the study suggest many problems in the preparatory year program that are reflected by the low level of student satisfaction, although the overall satisfaction is moderate. Thus, it means that the minimum academic and non-academic services have not been implemented properly in accordance with the accepted standards of preparatory year, so the services did not meet the expectations of the direct beneficiaries (the students), let alone meet the expectations of other beneficiaries that do not receive the services directly. The results of this study are consistent in terms of the average student satisfaction with the results of some previous studies(e.g., Abbasi, Malik, Chaudhry and Imdadullah, 2011; Amarat and Thawabieh, 2011; Algodah and Khleafat, 2013; Saif, Sartawi and Aqra, 2014). However, they differ from the results of Bani Hamdan (2012) study which demonstrated high levels of student satisfaction, and at the same time, differ from the results of Hassania study (2009) which demonstrated low levels of student satisfaction in the most fields of satisfaction targeted by the study.

For further illustration, table 4 displays the results of the sample participants' responses to each item of the satisfaction scale dimensions in descending order within each dimension according to the average and percentage values. Thus, it is clear that the study sample participants reported a higher level of satisfaction in their responses to items $22,45,19,38,6,30$, while the lowest reported level of satisfaction in their responses was to items $34,4,31,40$, 30 .

Table 4. Average, Percentages, and Item Score

\begin{tabular}{|c|c|c|c|c|}
\hline No & Item/Dimension & Avg. & $\%$ & Level \\
\hline $\mathbf{C}$ & Dimension of Exams and Evaluation & 3.17 & 63.5 & Average \\
\hline 19 & The opinions of students are taken when determining the dates of tests. & 3.69 & 73.8 & High \\
\hline 22 & $\begin{array}{l}\text { The management of student evaluation processes is characterized by seriousness and } \\
\text { firmness. }\end{array}$ & 3.67 & 73.4 & High \\
\hline 21 & $\begin{array}{l}\text { The students obtain detailed feedback on all their assignments during the semester } \\
\text { (tests, essays, projects, presentations). }\end{array}$ & 3.24 & 64.8 & Average \\
\hline 20 & $\begin{array}{l}\text { The student evaluation methods focus on the higher mental processes (analysis, } \\
\text { synthesis, making judgments). }\end{array}$ & 3.04 & 60.8 & Average \\
\hline 23 & $\begin{array}{l}\text { The management of student evaluation processes is characterized by justice and } \\
\text { objectivity. }\end{array}$ & 2.96 & 59.2 & Average \\
\hline 18 & The student evaluation methods are compatible with the used teaching methods. & 2.45 & 49.0 & Average \\
\hline $\mathbf{D}$ & Dimension of Management of Student Affairs & 3.15 & 63.1 & Average \\
\hline 24 & $\begin{array}{l}\text { The effectiveness of electronic systems used in the admission and registration } \\
\text { processes. }\end{array}$ & 3.85 & 77.0 & High \\
\hline 27 & $\begin{array}{l}\text { Availability of declared regulations which govern the students' behavior and clarify } \\
\text { their rights and responsibilities. }\end{array}$ & 3.54 & 70.8 & Average \\
\hline 25 & Availability of public information and extension services. & 3.49 & 69.8 & Average \\
\hline 29 & Availability of social interaction's requirements within organized activities. & 3.20 & 64.0 & Average \\
\hline 26 & A availability of diverse student activities to meet the different needs of students. & 2.79 & 55.8 & Average \\
\hline 28 & Availability of psychological and social counseling services. & 2.06 & 41.2 & Low \\
\hline $\mathbf{A}$ & Dimension of Faculty Members and Teaching Methods & 2.66 & 53 & Average \\
\hline 6 & $\begin{array}{l}\text { The faculty members provide students with all requirements of the courses at the } \\
\text { beginning of each semester. }\end{array}$ & 3.76 & 75.2 & High \\
\hline 7 & $\begin{array}{l}\text { The faculty members use multiple teaching methods that encourage self-learning for } \\
\text { students. }\end{array}$ & 3.42 & 68.4 & Average \\
\hline 8 & $\begin{array}{l}\text { The faculty members focus on the diversity of teaching methods to make the process of } \\
\text { teaching and learning an enjoyable process. }\end{array}$ & 3.18 & 63.6 & Average \\
\hline 11 & $\begin{array}{l}\text { The faculty members consider the individual differences between students in diverse } \\
\text { educational situations. }\end{array}$ & 2.97 & 59.4 & Average \\
\hline 9 & The faculty members encourage students to get into beneficial dialogues and & 2.51 & 50.2 & Average \\
\hline
\end{tabular}


purposeful discussions.

3 The faculty members are serious when they teach program courses.

$2.49 \quad 49.8 \quad$ Average

2 The faculty members employ modern techniques in the teaching of courses.

$2.35 \quad 47.0 \quad$ Average

The faculty members have large capacities to clarify information and ideas.

$2.33 \quad 46.6 \quad$ Low

5 The faculty members have scientific qualifications commensurate with the courses

$2.28 \quad 45.6 \quad$ Low they teach.

10 The faculty members use various teaching methods that push students to meditation

$2.19 \quad 43.8 \quad$ Low and thinking away from conservation and indoctrination.

4 The faculty members commit to teaching lectures from the first day of each semester.

\begin{tabular}{cc}
\hline G & Dimension of Facilities and Support Services \\
\hline 45 & The quality of educational physical environment (buildings, halls, parking,
\end{tabular}
restaurants).

46 Availability of all safety requirements in facilities and equipment.

50 Achieving discipline and respect for the system within the campus of the university.

47 The effectiveness of physical and technological teaching tools in the classrooms.

49 The quality of support services on campus (health care, housing, feeding, maintenance, cleanliness).

48 Availability of facilities and services dedicated to people with special needs.

$\begin{array}{lll}1.76 & 35.2 \quad \text { Low }\end{array}$

\begin{tabular}{ccc}
$\mathbf{2 . 6 4}$ & $\mathbf{5 2 . 7}$ & Average \\
\hline 3.68 & 73.6 & High
\end{tabular}

\begin{tabular}{cl}
\hline B & \multicolumn{1}{c}{ Dimension of Course Content } \\
\hline 13 & $\begin{array}{l}\text { The course content develops the capabilities and skills of students to deal with diverse } \\
\text { problems. }\end{array}$
\end{tabular}

17 The program courses have laboratories and necessary centers to implement their

$3.12 \quad 62.4 \quad$ Average

$2.70 \quad 54.0 \quad$ Average

$2.14 \quad 42.8 \quad$ Low

$2.11 \quad 42.2 \quad$ Low contents.

12 The course content encourages students to be creative and innovative.

16 The course content is characterized by suspense and attracting the attention of the students.

14 The course content is characterized by modernity and keeps up with the latest developments in the targeted fields.

15 The course content is in line with the academic and professional future directions of the students.

$2.07 \quad 41.4$ Low

$\mathbf{2 . 5 2} \quad \mathbf{5 0 . 4}$ Average

$\begin{array}{lll}3.32 & 66.4 & \text { Average }\end{array}$

$2.68 \quad 53.6 \quad$ Average

$2.41 \quad 48.2 \quad$ Average

$2.34 \quad 46.8$ Average

$2.23 \quad 44.6 \quad$ Low

$2.15 \quad 43.0 \quad$ Low

\begin{tabular}{|c|c|c|c|c|}
\hline $\mathbf{F}$ & Dimension of Learning Resources & 2.40 & 48.0 & Average \\
\hline 38 & Availability of curriculums and scientific references at a timely manner. & 3.71 & 74.2 & High \\
\hline 44 & $\begin{array}{l}\text { Matching of staff specialties with their nature of work to provide the necessary support } \\
\text { to beneficiaries. }\end{array}$ & 2.87 & 57.4 & Average \\
\hline 39 & $\begin{array}{l}\text { The effectiveness of electronic systems that facilitate access to information sources } \\
\text { and databases. }\end{array}$ & 2.58 & 51.6 & Average \\
\hline 42 & Availability of appropriate places for individual and collective reading. & 2.25 & 45.0 & Low \\
\hline 41 & The p & 2.16 & 43.2 & Low \\
\hline 43 & ing programs to support students on how to take & 2.01 & 40.2 & Low \\
\hline 40 & $\begin{array}{l}\text { The scope of a variety of services (computers, the global Internet, printers and imaging } \\
\text { devices supported by self-payment system, technical support). }\end{array}$ & 1.22 & 24.4 & $\mathrm{~L}$ \\
\hline $\mathbf{E}$ & Dimension of Academic Advising & 2.02 & 40.4 & Low \\
\hline 37 & Follc & 2.47 & 49.4 & Average \\
\hline 32 & Assis & 2.39 & 47.8 & Average \\
\hline 33 & Advi & 2.35 & 47.0 & Average \\
\hline 36 & 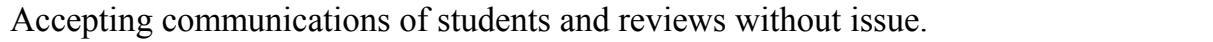 & 2.16 & 43.2 & Low \\
\hline 35 & Know & 2.07 & 41.4 & Low \\
\hline 34 & Givil & 1.89 & 37.8 & Low \\
\hline 31 & $\begin{array}{l}\text { Commitment of academic advisor with office hours according to the declared } \\
\text { schedule. }\end{array}$ & 1.66 & 33.2 & Low \\
\hline 30 & Nominating an academic advisor for each stude & 1.13 & 22.6 & Low \\
\hline \multicolumn{2}{|c|}{ Satisfaction overall } & 2.65 & 53.0 & Average \\
\hline
\end{tabular}




\subsection{Results Related to the Study Hypotheses}

T-test is used for independent samples to test the hypotheses of the study. Tables 5, 6, and 7 present the results of t-test.

\subsubsection{Hypothesis 1}

The data in Table 5 indicates that the variable gender was not an important factor in determining the level of student satisfaction with the services they receive, as the value of significance equals to 0.836 , which is larger than the certified alpha value (0.05). This result supports the first hypothesis. It is also consistent with the findings of some researchers, such as Abbasi, Malik, Chaudhry, and Imdadullah (2011), Amarat and Thawabieh (2011), and Hasania (2009). In contrast, we find that they differ from the study results of Saif, Sartawi and Aqra (2014) that proved the variable gender effect on student satisfaction, and this was done for the benefit of female students.

Table 5. Results of T-test for Student Satisfaction Based on Gender

\begin{tabular}{ccccccc}
\hline Independent Variable & Level & Number & Avg. & SD & t-Value & Significance \\
\hline \multirow{2}{*}{ Gender } & Male & 183 & 2.71 & 0.361 & \multirow{2}{*}{0.067} & \multirow{2}{*}{0.836} \\
& Female & 167 & 2.57 & 0.523 & \\
\end{tabular}

* Statistically significant at the level of $(\alpha \leq 0.05)$

\subsubsection{Hypothesis 2}

The data in Table 6 indicates that the total variable is not an important factor in determining the level of student satisfaction, as the value of significance equals 0.328 , larger than the certified alpha value (0.05). Accordingly, there is harmony in the level of student satisfaction regardless of the college to which they belong, whether their specialization is scientific or literary. This result supports the second hypothesis, but it differs from the result of Amarat and Thawabieh study (2011), which demonstrated statistically significant differences in student satisfaction attributed to the variable of college.

Table 6. Results of T-test for Student Satisfaction Based on College

\begin{tabular}{ccccccc}
\hline Independent Variable & Level & Number & Avg. & SD & t-value & Significance \\
\hline \multirow{2}{*}{ College } & scientific disciplines & 163 & 2.71 & 0.504 & \multirow{2}{*}{0.466} & \multirow{2}{*}{0.328} \\
& literary disciplines & 187 & 2.60 & 0.437 & \\
\hline
\end{tabular}

* Statistically significant at the level of $(\alpha \leq 0.05)$

\subsubsection{Hypothesis3}

Table 7 shows statistically significant differences among the student satisfaction averages attributed to the variable distance between housing and university at a significance level of 0.01 , which is lower than the certified significance level value (0.05). Therefore, we reject the third null hypothesis, and prove that a variable distance between the housing and the university is an important factor in the level of student satisfaction. This result means that students who walk $20 \mathrm{~km}$ or less between the housing and the university are more satisfied than those who travel more than $20 \mathrm{~km}$. This is clarified by the arithmetic average of the first category reaching 2.82 , when it is compared to the arithmetic average of the second category, which stood at 2.49. In general, this is a logical consequence, since the students who live in areas far from the university are facing the problem of lacking the opportunity to benefit from the university services for long periods fitting in with their schedules and needs along with the lack of alternatives available to them. In addition, the majority of students, especially females, are tied by joint transportation and specific hours by which they had to abide.

Table 7. Results of T-test for Student Satisfaction Based on Distance

\begin{tabular}{ccccccc}
\hline Independent Variable & Level & Number & Avg. & $S D$ & t-value & Significance \\
\hline \multirow{2}{*}{ Distance } & $\leq 20 \mathrm{~km}$ & 84 & 2.82 & 0.407 & \multirow{2}{*}{3.462} & \multirow{2}{*}{$0.01^{*}$} \\
& $>20 \mathrm{~km}$ & 266 & 2.49 & 0.596 & & \\
\end{tabular}

* Statistically significant at the level of $(\alpha \leq 0.05)$ 


\section{Recommendations}

1. Deanship of preparatory year needs to rush to improve student service fields of low satisfaction categories that did not realize student needs, especially with regard to the academic counseling field.

2. There is a need for periodical annual evaluation for preparatory year in accordance with specific and clear criteria including all customers, operators, and everyone who is related to the program and taking into account the expectations and needs of all beneficiaries with retaining the evaluation records and results.

3. Avoiding the repetition of unsuccessful experiments in the preparatory year employment and not allowing the non-qualified individuals or institutions to market their services and achieve personal gains at the expense of the university outputs.

4. Continuously developing student services, whether academic or non-academic, and providing the necessary infrastructure in line with modern technological developments in the educational environment.

5. Paying attention to student satisfaction and working on measuring it continuously to take the results of the measurement as a mirror that reflects the quality level of university services provided for them.

6. It is important for the university to adopt the standards of academic quality and accreditation and commit to them in all programs, colleges, and departments as a response to modern variables and intense competition among college graduates in the labor market.

7. The university should encourage and support research, seminars, and scientific conferences to maximize their role in exposing the weaknesses and addressing the problems.

\section{References}

Abbasi, M. N., Malik, A., Chaudhry, I. S., \& Imdadullah, M. (2011). A study on student satisfaction in pakistani universities: The case of bahauddin zakariya university, pakistan. Asian Social Science, 7(7), 209-219.

Al-Qudah, M., \& Khleifat, A. (2013). The degree of satisfaction of mutah university students for university services from their point of view. Al manarah Journal, 19(1), 257-494.

Amarat, M., \& Thawabieh, A. (2011). Constructing an instrument to measure student's satisfaction about studying at tafila technical university. Journal of Educational and Psychological Sciences, 12(3), 79-111.

Association of American Colleges \& Universities. (2007). College learning for the new global century. Washington, DC: Association of American Colleges \& Universities.

Astin, A. (1993). What matters in college? four critical years revisited. San Francisco,CA: Jossey-Bass.

Bani Hamdan, K. (2012). In Mona Al Zayani (Chair). The effect of educational service quality on students' satisfaction at applied science private university. In Proceedings of The Second International Arab Conference on Quality Assurance in Higher Education (pp. 917-929). Retrieved from http://library.birzeit.edu/librarya/files/kitab.pdf

Bernhard, A. (2011). Quality Assurance in an International Higher Education Area. Dordrecht: Springer. http://dx.doi.org/10.1007/978-3-531-94298-8

Budic, H. (2011). Importance and application of test method in the process of determining student's satisfaction with the quality of educational services. International Journal of Management Cases, 3(8), 368-375. http://dx.doi.org/10.5848/APBJ.2011.00073

DeShields, Oscar W., Kara, A., \& Kaynak, E. (2005). Determinants of business student satisfaction and retention in higher education: Applying herzberg's two-factor theory. The International Journal of Educational Management, 19(2), 128-139. http://dx.doi.org/10.1108/09513540510582426

Douglas, J., McClelland, R., \& Davies, J. (2008). The development of a conceptual model of student satisfaction with their experience in higher education. Quality Assurance in Education, 16(1), 19-35. http://dx.doi.org/10.1108/09684880810848396

Greenfield, G.M., Keup, J.R., \& Gardner, J.N. (2013). Developing and Sustaining Successful First-Year Programs: A Guide for Practitioners. Somerset, NJ, USA: John Wiley \& Sons.

Harvey, L., \& Akling, B. (2003). Quality in Higher Education. In: Begg, R. (Ed.), Kluwer Academic Publishers, ProQuest ebrary. Web. 1 July (pp. 69-83). Retrieved from http://goo.gl/j5c7pb 
Hassania, S. (2009). Degree of satisfaction of students of economics faculty in the University of Aleppo with the level of administrative and academic performance of their college. Journal of Damascus University for Science Economic and Legal, 25(2), 285-312.

Hosseini, K. (2012, April 14). An independent committee studies the «negatives and positives» in preparation for the consideration from the shura council - the frustration of preparatory year.!. Al-Riyadh Newspaper. Retrieved from http://www.alriyadh.com/727060

Howell, G. G., \& Buck, J. J. (2012). The Adult Student and Course Satisfaction: What Matters Most?. Innovative Higher Education, 37(3), 215-226. http://dx.doi.org/10.1007/s10755-011-9201-0

Hussey, T., \& Patrick, S. (2010). The trouble with higher education: A critical examination of our universities. New York, NY: Routledge Group.

Ilias, K., \& Nor, M. M. (2012). Student satisfaction based on service quality in teachers' training institution in Malaysia. A retrospective. Academic Research International, 2(3), 367-373.

Kamel, J. (2015, April). Preparatory year programs at the Saudi universities "a reading in the paradox between philosophy and structure". Paper presented at the First National Conference of Preparatory Year in Saudi Universities, Dammam, Saudi Arabia. Abstract retrieved from http://prep1 sa.uod.edu.sa/Default.aspx

Khalil, R. (2010). Learning reconsidered: Supporting the preparatory year student experience. Procedia - Social and Behavioral Sciences, 9, 1747-1756. http://dx.doi.org/10.1016/j.sbspro.2010.12.394

Koch, A. K., \& Gardner, J. N. (2006). The history of the first-year experience in the United States: Lessons from the past, practices in the present, and implications for the future. In A. Hamana \& K. Tatsuo (Eds.), The first-year experience and transition from high school to college: An international study of content and pedagogy. Tokyo, Japan: Maruzen Publishing.

Lal, Z. (1999). General habilitation programs - did they perform the purpose? Satisfaction with the study in graduate programs from the perspective of male and female students in some Saudi Universities. Journal of Association of Arab Universities, 35, 28-35.

Mansori, S., Vaz, A., \& Ismail, Z. (2014). Service quality, satisfaction and student loyalty in malaysian private education. Asian Social Science, 10(7), 57-66.

Mohammed, M. (2004). Satisfaction with the school for students of the faculty of education in Ibb University. Journal of Association of Arab Universities, 44, 77-103.

Nabhan, M. (2001). The development of a tool to measure the degree of satisfaction with the study at the faculty of educational sciences at Mutah University. Journal of Educational Research Center, University of Qatar, 20, 125-152.

National Commission for Academic Accreditation \& Assessment. (NCAAA). (2011). The standards of quality assurance and academic accreditation of institutions of higher education. Retrieved from NCAAA website: http://www.ncaaa.org.sa/

Pascarella , E., \& Terenzini, P. (2005). How college affects students: A third decade of research. (1 ed., Vol. 2). San Francisco: Jossey-Bass higher and adult education series.

Rice, D. (2015, April). Going Up the Down Staircase: The Dichotomy Facing $21^{\text {st }}$ Century Preparation Programs in the Middle East. Paper presented at the First National Conference of Preparatory Year in Saudi Universities, Dammam, Saudi Arabia. Abstract Retrieved from http://prep1sa.uod.edu.sa/Default.aspx

Roszkowski, M., \& Ricci, R. (2004). Measurement of Importance in a Student Satisfaction Questionnaire: Comparison of the Direct and Indirect Methods for Establishing Attribute Importance. Journal of College Student Retention: Research, Theory and Practice, 6(3), 251-271. http://dx.doi.org/10.2190/GEPA-2RNR-GK7P-5JMC

Ryals, L. (2002). Are your customers worth more than money?. Journal of Retailing and Consumer Services, 9(5), 241-251. http://dx.doi.org/ 10.1016/S0969-6989(02)00005-X

Sarmi, A., \& Zayed, K. (2006). The degree of student satisfaction of the educational college at Sultan Qaboos University for academic supervision and the nature of their expectations of it. Journal of the Faculty of Education, the United Arab Emirates University, 23, 59-88.

Solinas, G., Masia, M. D., Maida, G., \& Muresu, E. (2012). What really affects student satisfaction? an assessment of quality through a university-wide student survey. Creative Education, 3(1), 37-40. 
http://dx.doi.org/10.4236/ce.2012.31006

Sumaedi, S., Bakti, I., \& Metasari, N. (2011). The effect of students' perceived service quality and perceived price on student satisfaction. Management Science and Engineering, 5(1), 88-97. http://dx.doi.org/10.3968\%2Fj.mse.1913035X20110501.010 